\title{
Investigation of the Relationship between the Self-confidence and Motivation of High School Students Participating School Sport Contests ${ }^{i}$
}

\author{
Sermet Toktas ${ }^{1, *}$, Mustafa Bas ${ }^{2}$ \\ ${ }^{1}$ School of Physical Education and Sports, Bayburt University, Turkey \\ ${ }^{2}$ Sport Science Faculty, Trabzon University, Turkey
}

Copyright@2019 by authors, all rights reserved. Authors agree that this article remains permanently open access under the terms of the Creative Commons Attribution License 4.0 International License

\begin{abstract}
The purpose of this study is to examine the relationships between the levels of self-confidence and motivation of high school students participating sport contests at school and the various demographic variables (gender, high school type, sport age, sports branch and sport category). In the study, survey model, which is frequently used in descriptive research method is used. The population of the study consisted of students who studied at high schools and those who attended contests in Adiyaman, while sample consisted of 856 athletes, $39 \%$ of whom were female students (334) and 61\% (522) of whom were male students. To collect data for the study, personal data form, "Motivation in Sport" scale, which was developed by Pelletier et al. (1995) and adapted to Turkish by Pelletier et al. and "Self-confidence" scale developed by Akın (2007) were used. SPSS 21.00 package program was used for data analysis. Multiple regression analysis, Pearson product-moment correlation co-efficient technique, independent t-test and one-way analysis of variance were performed in the quantitative data of the research. According to the findings obtained from the study, it was determined that there was a significant relationship between demographic information and self-confidence and motivation levels. While there was a significant difference in gender self-confidence level with intrinsic and extrinsic self-confidence and high school type sports branch, there was no significant difference between sport age and sport category. A significant relationship was found between the sub-dimension of non-motivation, intrinsic motivation and extrinsic motivation, and there was no significant relationship with other independent variables such as gender, sports branch, sport category and sport age. Based on these results, it is recommended that secondary school students participate in sports competitions to have some elements that may have positive effects on their self-confidence and motivation.
\end{abstract}

Keywords Self-confidence, Motivation, Student,
Sport

\section{Introduction}

Both the physical and spiritual maturity of the young generations who are teenagers or adults directly affect the future of nations. The importance given to people and education is important in civilization. Education aims to help individuals develop their expected strengths and abilities. Among the most basic principles of contemporary education is to educate individuals in all aspects; physically, mentally and emotionally (Araci, 2006). As it is known, sport is a multidimensional social phenomenon with its physiological, psychological and biological aspects besides having its own content (Yaman and Duman, 2004).

Sports provides individuals with a number of benefits, such as being aware of their own abilities and others', as well as accepting defeat, using time to compete in equal conditions. For this reason, sports, as an important tool of contemporary education system, aims to prepare individuals for life (Erciş, 2012). In recent years, the increase in the importance given to sports is actually an increase in the importance given to education (Özkara, 2018).

The aim of each individual in sports activities is to increase their performance. In this process individuals show different kinds of behaviours both physically and psychologically in order to achieve their goals. (Abakay, 2010).

Sport includes activities that require the application of complex physical skills or physical effort, as well as it is based on institutionalized competitive activities that are motivated internally and externally. (Yetim and Cengiz, 2010). People in contemporary societies are constantly racing and in a state of change. For this reason, individuals 
who are in competition must follow continuous change and development in order to be successful (Kılınç et al., 2012). It is generally accepted that the motivation of success is developed by the sense of competition that exists in the nature of sports. (Aktaş, Çobanoğlu, Yazıcılar \& Er, 2006). Success motivation is defined as doing an ingenious job and overcoming the obstacles that will be faced and accomplishing something better than other athletes do. (Kılınç et al., 2012). The effect of the quality of physical and psychological performances of athletes (Özkara et al., 2017), usually depends on their motivation. In his research Çam (1990) states that motivation is factor that affects performance and that performance and motivation decrease and multiply in direct proportion to each other (Turkmen, 2005). Özkara, Kalkavan Alemdağ and Alemdağ (2016) stated that in addition to being a supporter of physical performance sports also affects psychological strength.

It has been stated that the feeling of self-confidence is a very important factor for the individual to have positive lives, to develop their own abilities and to use their positive aspects for the sake of being a successful individual (Ekinci, 2013). It is closely related to the self-confidence of the individuals who have high motivation to do a work, because individuals with low self-esteem avoid making effort to reach their goals. (Ekinci, 2013).

Self-confidence, defined as an individual's belief in talents, judgment, power and decisions, is an important feature in school life, personal and social life. The concept of inner self-esteem, which includes self-awareness, self-esteem and self-reflection, shows that the individual is aware of himself on this subject. The ability to express oneself, to communicate, to control their emotions is related to extrinsic self-confidence and is the image and impression given to the outside as being slef-confident. (Bilgin, 2011).

Motivation can be defined as the systems that force the organism to action, determine the regularity and continuity of these actions, and provide different extrinsic and internal factors that lead to the behavior and actions and the coordination of these. (Kılınç, Ulucan, Kaya and Türkçapar, 2012). Researchers who consider motivation as intrinsic and extrinsic motivation define external influences as repression, reward, intelligence, and intrinsic motivation as curiosity, interest and need while they define intrinsic motivation as something that come from inner side of people. (Öncü, 2003). The researchers reported that intrinsic motivation factors are more motivated to beginners in the sport and cause less wear. Those who begin to do sports due to internal reasons tend to gain new abilities, adopt team spirit and gain self-confidence and show high performance. Because, the priority of those who turn to sports with external reasons is to raise social status, to develop and to gain professional career (Şirin, Çağlayan, Çetin and Alparslan, 2008).

Considering all these issues, it was seen that researching the factors that affect the self-confidence and motivation of adolescent youth is considered as a worthwhile study.

\section{Method}

In this chapter, there will be information about research group, research model, data collection, data collection tools and data analysis.

\subsection{Research Group}

The population of this study is a total of 2722 athletes studying in high schools and participating in high school sports competitions in 2015-2016 school year, in the center of Adiyaman province, while sample includes 856 students \%39 (334) of whom are female; \%61(522) of whom were male students. According to the data received from Adiyaman Youth and Sports Provincial Directorate in 2015-2016 academic year 2722 athletes in total participated in high school sport competitions.

\subsection{Data Collection}

After considering the subject and purpose of the study, statistical data between independent variables and dependent variables are required. The advantages of the scales are low cost, being strong in protecting the privacy of the investigators, minimizing errors in situations such as prejudice and personal tendency, giving answers after some thinking time and easier access. (Ekiz, 2013).

Before the scales were applied, necessary permissions were obtained from the Adıyaman Provincial Directorate of National Education for the application of the scales to students by means of the Student Affairs Department of Black Sea Technical University. The scale forms were given to 916 students. However, 856 scale form was included in our study because 60 of them weren't filled completely or coded in the same way continuously. In our study, the application of the scales was delivered to the students at least 1.5 hours before the competition time and they were asked to answer the scales carefully by making necessary explanations under the supervision of the investigator. The completed scales were re-collected by the researcher.

\subsubsection{Data Collection Tools}

In our research, "Personal Information Form" which was developed by the researcher and the experts in the field; "Sports Motivation Scale" which was developed by Pelletier et al. And in 1995 and adapted to Turkish by Kazak in 2004 and "Self Confidence Scale" which was developed by Akın in 2007 were applied.

When the internal consistency values calculated with Cronbach alpha of sports motivation scale were examined, it was determined that the Cronbach alpha coefficients were .88 for intrinsic motivation to know-accomplishment, .73 for intrinsic motivation to experience stimulation, .82 for introjection, .72 for 
identification, .74 for external regulation and .70 for motivation subscales. In order to determine the consistency between the applications at different times, the test-retest correlation coefficients of 4 -week intervals were found to vary between .52 and .91 .

The self-confidence scale consists of two sub-dimensions, internal and external self-confidence. The factor loadings of the scale are between 31 and 75 . In the confirmatory factor analysis conducted to confirm the two-factor structure of the scale, the fit index values were found as RMSEA $=.044, \mathrm{NFI}=.90, \mathrm{CFI}=.96, \mathrm{IFI}=.96$, $\mathrm{RFI}=.89$, GFI $=.94$, AGFI $=.91$ and SRMR, and the internal consistency coefficients of the Self-confidence Scale were determined to be .83 and .83 , respectively, for the self-confidence and self-confidence subscales. 85 . Test-retest reliability coefficients of the scale were found to be 94 for the whole scale, 97 for the internal self-confidence subscale and .87 for the external self-confidence.

\section{Findings}

\subsection{Demographic Characteristics of Secondary School Students}

In this section, statistical analyzes of the relationships between the self-confidence and motivation levels of high school students participating in sports competitions are included. The descriptive statistics of the characteristics determined primarily in accordance with the sub-objectives determined within the scope of the study, and then the findings related to the independent variables obtained from the personal information of the participants are included. In addition, the relationships between the self-confidence and motivation levels of the secondary school students and the findings about the self-confidence and motivation levels of the students are given.

Table 1. Descriptive Information on Demographic Variables

\begin{tabular}{|c|c|c|c|}
\hline & Variable & $\mathrm{n}$ & $\%$ \\
\hline \multirow{3}{*}{ Gender } & Male & 522 & 61,0 \\
\hline & Female & 334 & 39,0 \\
\hline & Total & 856 & 100,0 \\
\hline \multirow{11}{*}{ High School Type } & Industrial Vocational (I) & 97 & 11,3 \\
\hline & Science (II) & 52 & 6,1 \\
\hline & Sports (III) & 106 & 12,4 \\
\hline & Anatolian (IV) & 278 & 32,5 \\
\hline & Trade $(\mathrm{V})$ & 59 & 6,9 \\
\hline & Girls Vocational (VI) & 64 & 7,5 \\
\hline & Imam Hatip (VII) & 101 & 11,8 \\
\hline & Medical Vocational (VIII) & 16 & 1,9 \\
\hline & Private (IX) & 67 & 7,8 \\
\hline & Other $(\mathrm{X})$ & 16 & 1,9 \\
\hline & Total & 856 & 100,0 \\
\hline \multirow{16}{*}{ Sports age } & $1-3$ & 368 & 43,0 \\
\hline & 4-6 & 274 & 32,0 \\
\hline & $7-9$ & 136 & 15,9 \\
\hline & 10 and above & 78 & 9,1 \\
\hline & Total & 856 & 100,0 \\
\hline & Football & 203 & 23,7 \\
\hline & Basketball & 143 & 16,7 \\
\hline & Volleyball & 120 & 14,0 \\
\hline & Chess & 31 & 3,6 \\
\hline & Table Tennis & 33 & 3,7 \\
\hline & Dart & 59 & 6,9 \\
\hline & Futsal & 178 & 20,8 \\
\hline & Tennis & 60 & 7,0 \\
\hline & Athletics & 17 & 2,0 \\
\hline & Orienteering & 12 & 1,4 \\
\hline & Total & 856 & 100,0 \\
\hline \multirow{3}{*}{ Sports Category } & Team Sports & 645 & 75,4 \\
\hline & Individual Sports & 211 & 24,6 \\
\hline & Total & 856 & 100,0 \\
\hline
\end{tabular}


Descriptive statistical findings of high school students participating in the study are summarized in Table 1. As shown in the table, $522(61.0 \%)$ of the students were male, $334(39.0 \%)$ were female; $97(11.3 \%)$ were students of Industrial Vocational High School, 52 (6.1\%) of Science High School, 106 (12.4\%) of Sports High School, 278 (32.5) of Anatolian High School, 59 (6,9\%) of Vocational High School, 64 (7.5\%) of Girls Vocational High School, 101 (11.8\%)of Imam Hatip High School, 16 (1.9\%) of Medical Vocational School while $67(\% 7,8)$ of them studied in other high schools and $(16,8 \%)$ of them studied in private high schools.368 $(43,0 \%)$ of them have been doing sports for 1-3 years, $274(32,0 \%)$ 4-6 years, 136 $(15,9 \%) 7-9$ years and $78(9,1 \%)$ have 10 years and above sports experience. $203(23.7 \%)$ of them were interested in football, 143 (16.7\%) basketball, 120 (14.0\%) volleyball, $31(\% 3,6)$ chess, $33(3,7 \%)$ table tennis, $59(6,9 \%)$ darts, $178(20,8 \%)$ futsal, $60(7,0 \%)$ tennis, $17(2.0 \%)$ of athletics and $12(1.4 \%)$ were interested in the orienteering sports branches. $645(75.4 \%)$ of them interested in the team sports and $211(24.6 \%)$ of them participated individual sports.

\subsection{Self-confidence Scale Score Analysis Results}

3.2.1. Findings Related to Measurements between Self Confidence and Gender, High School Type, Sport Branch, Sport Category and Sport Branch Variables

When we look at Table 2, a significant difference was found between the intrinsic self-confidence scores of the participants and the $t$-test between the variables of $t=1,749$ and $p<.05$. When the mean scores of the groups were found to be in favor of this group, it was found that the male $(X=64,50)$ female $(X=62,82)$ male scores were higher than the female scores. This finding shows that there is a significant relationship between the intrinsic self-confidence and gender of secondary school students.

As shown in Table 3, there was a significant difference between the participants' intrinsic self-confidence [F $(9 / 846)=2.43$ scores and extrinsic self-confidence $[\mathrm{F}(9 / 846)=2,36 ; \mathrm{P}<.05]$ scores.

As shown in Table 4, it was found that there was a significant difference between intrinsic self-confidence [F $(11 / 844)=3,23 ; \quad \mathrm{P}<.05]$ scores and extrinsic self-confidence scores according to the sports branch variable of the participants. No meaningful relationship was found between sport age and sport category and self-confidence.

Table 2. T- Test Results of Self-confidence Sub-dimensions of Participants according to Gender Variable

\begin{tabular}{ccccccc}
\hline Variables & $\mathrm{F}$ & $\mathrm{N}$ & $\mathrm{Mean}$ & $\mathrm{Ss}$ & $\mathrm{t}$ & $\mathrm{P}$ \\
\hline \multirow{2}{*}{ Inner self-confidence } & $\mathrm{M}$ & 522 & 64,50 & 13,19152 & \multirow{2}{*}{1,749} &, $020^{*}$ \\
\cline { 2 - 5 } & $\mathrm{F}$ & 334 & 62,82 & 14,42199 & \multirow{2}{*}{, 777} &, 084 \\
\hline \multirow{2}{*}{ Outer self-confidence } & $\mathrm{M}$ & 522 & 60,56 & 12,75115 & 13,43331 & \\
\cline { 2 - 5 } & $\mathrm{F}$ & 334 & 59,85 & & & \\
\hline
\end{tabular}

Table 3. One-Way Anova Results of Self-confidence by High School Type Variables

\begin{tabular}{|c|c|c|c|c|c|}
\hline Variables & VARIABLE SOURCE & $\mathrm{Kt}$ & $\mathrm{Sd}$ & $\mathrm{KO}$ & $\mathrm{F}$ \\
\hline \multirow{3}{*}{ Intrinsic Self-confidence } & Intergroup & 4055,089 & 9 & 450,565 & \multirow{3}{*}{2,43} \\
\hline & In-group & 156442,470 & 846 & \multirow{2}{*}{184,920} & \\
\hline & Total & 160497,560 & 855 & & \\
\hline \multirow{3}{*}{ Extrinsic Self-confidence } & Intergroup & 3559,684 & 9 & 395,520 & \multirow{3}{*}{2,36} \\
\hline & In-group & 141344,044 & 846 & \multirow{2}{*}{167,073} & \\
\hline & Total & 144903,728 & 855 & & \\
\hline
\end{tabular}

Table 4. One-Way Anova Results Regarding Participants' Self-confidence by Sport Branch Variable

\begin{tabular}{|c|c|c|c|c|c|c|}
\hline Variables & VARIABLE SOURCE & $\mathrm{Kt}$ & $\mathrm{Sd}$ & $\mathrm{KO}$ & F & $P$ \\
\hline \multirow{3}{*}{$\begin{array}{c}\text { İnternal } \\
\text { Self-confidence }\end{array}$} & Intergroup & 6487,575 & 11 & 589,780 & \multirow{3}{*}{3,23} & \multirow{3}{*}{, 000} \\
\hline & In-group & 154009,985 & 844 & \multirow{2}{*}{182,476} & & \\
\hline & Total & 160497,560 & 855 & & & \\
\hline \multirow{3}{*}{$\begin{array}{c}\text { Extrinsic } \\
\text { Self-confidence }\end{array}$} & Intergroup & 5546,247 & 11 & 504,204 & \multirow{3}{*}{3,05} & \multirow{3}{*}{001} \\
\hline & In-group & 139357,481 & 844 & \multirow{2}{*}{165,115} & & \\
\hline & Total & 144903,728 & 855 & & & \\
\hline
\end{tabular}


Table 5. One-Way Anova Results Regarding the Motivation of the Participants by High School Type Variable

\begin{tabular}{|c|c|c|c|c|c|c|}
\hline Variables & VARIABLE SOURCE & $\mathrm{Kt}$ & $\mathrm{Sd}$ & $\mathrm{KO}$ & $\mathrm{F}$ & $\mathrm{P}$ \\
\hline \multirow{3}{*}{ İnternal Self-confidence } & Intergroup & 6313,747 & 9 & 701,527 & \multirow{3}{*}{3,17} & \multirow{3}{*}{, 001} \\
\hline & In-group & 186717,823 & 846 & \multirow{2}{*}{220,707} & & \\
\hline & Total & 193031,570 & 855 & & & \\
\hline \multirow{3}{*}{ Extrinsic Self-confidence } & Intergroup & 6871,927 & 9 & 763,547 & \multirow{3}{*}{3,86} & \multirow{3}{*}{, 000} \\
\hline & In-group & 167361,788 & 846 & \multirow{2}{*}{197,827} & & \\
\hline & Total & 174233,715 & 855 & & & \\
\hline \multirow{3}{*}{ Non-motivation } & Intergroup & 780,502 & 9 & 86,722 & \multirow{3}{*}{2,60} & \multirow{3}{*}{, 006} \\
\hline & In-group & 28215,964 & 846 & \multirow{2}{*}{33,352} & & \\
\hline & Total & 28996,466 & 855 & & & \\
\hline
\end{tabular}

\subsection{Motivation Scale Score Analysis Results}

3.3.1. Findings Related to Motivation and Gender, High School Type, Sport Age, Sport Category and Sport Branch Variables

As shown in Table 5, the intrinsic motivation of the participants according to the high school type variable $[\mathrm{F}$ $(9 / 846)=3,17 ; \mathrm{P}<.05]$, extrinsic motivation $[\mathrm{F}(9 / 846)=$ $3,86 ; \mathrm{P}<.05]$ and $[\mathrm{F}(9 / 846)=2.60 ; \mathrm{P}<.05]$. There was no relationship between the sub-dimensions of non-motivation, intrinsic motivation, extrinsic motivation and gender, sport age, sport category and sports branch.

\section{Discussion}

\subsection{Assessment of Measures between Self-confidence, Gender, High School Type, Sports Age, Sports Branch and Sport Category Variables}

According to the results of the analysis; It was concluded that there is no statistically significant difference between the self-confidence sub-dimensions of self-confidence according to the gender variable and there is a significant difference between the intrinsic self-confidence sub-dimension. Accordingly, it was found that the scores of men were higher than the scores of women. This finding shows that there is a significant relationship between the intrinsic self-confidence and gender of secondary school students. Therefore, it can be said that men have high intrinsic self-confidence that they have to feel themselves more powerful than women and they want to prove themselves in sports competitions. In his research titled "Comparison of self-confidence levels of students who participated in scouting and not participating in the scouting activities" Kutlu (2001) found that male students have higher self-confidence than female students. This result also supports our study. The fact that male students prioritize themselves in the events requiring power speed, have a more muscular tissue and a strong sense of aggression when they exhibit their aggressive energies and have high self-esteem according to female students. That we have a patriarchal family structure, especially levels of self-confidence of male students in rural areas can be said to be higher than female students.

According to the results of the analysis, it was found that there was a significant difference between the intrinsic and self-confidence scores of the secondary school students who participated in the research according to the high school type variable. Accordingly, on the internal self-confidence and internal self-esteem dimension, the mean score of the students studying at the school I was found to be higher than the average scores of the students studying in other school types.

Therefore, the positive responses of high school students who are successful in sports competitions can provide self-satisfaction and self-confidence by providing the individual to develop positive attitudes towards themselves and their environment. It can be said that the coaches and teachers who are reassuring and supportive can help students realize themselves by positively affecting their self-confidence. Therefore, many students who think that they fail in school courses are guiding themselves to different fields. Students who are successful in sports competitions can be seen to be generally unsuccessful students and the student who fails in their courses tries to be successful in different areas in order to be successful. In such cases, it can be observed that there is a significant increase in the self-confidence levels of the students participating in sports competitions. It can be said that School I students participating in the sports competition make better decisions, and they are more successful and happier compared to the students participating in sports competitions in schools X. And the fact that they can say whatever they want to say before and after the competition without any hesitation contributed their self-confidence. Arslan, Doğanay, Kırık, and Çetinkaya (2015) concluded that the high school type variable did not cause a significant difference in self-confidence in the research named 'Relationship between sports and self-confidence in high school students" Ars. Ryan and Dzewaltowski (2002) found that 6 th and 7 th grade students increased their 
self-confidence through physical activity.

According to the results of the analysis, it was found that there was a significant difference between the self-confidence sub-dimension of self-confidence scores and extrinsic self-confidence scores of the secondary school students participating in the study. According to this, it is determined that the mean score of football is higher than the average scores of the secondary school students participating in basketball, volleyball, chess, table tennis, bocce, dart, futsal, tennis, athletics, orienteering sport competitions.

On the other hand, it was determined that the average score of football was higher than the average scores of secondary school students participating in basketball, volleyball chess, table tennis, bocce, dart, futsal, tennis, athletics, orienteering sports competitions. Therefore, football self-confidence and extrinsic self-confidence in the size of the football branch is higher than other sports branches because of the attractiveness of the large masses of football and the capacity of the athletes to perform, more enjoyable and more successful results can be said to be effective. Ozturk et al. (2007), in their research, concluded that the handball practices enabled individuals to see themselves more self-confident because of the ability to develop talents, to express themselves, to acquire new skills, to develop new relationships and to create a sense of living.

According to the results of the analysis, there is no significant difference between the intrinsic self-confidence and extrinsic self-confidence scores according to the sports category and sports age variables of the secondary school students participating in the research.

According to the results of the analysis, there is no significant difference between the internal self-confidence and external self-confidence scores of the secondary school students participating in the study according to the sport age variable. Hofstetter, Hovell and Sallis (1990) support the results of our study in their study on individuals who started sports at an early age.

According to the results of the analysis, there is no significant difference between the self-confidence and external self-confidence scores of the secondary school students participating in the research according to the sports category variable. Arslan et al. (2015) found that high school students engaged in indivual sports or team sports did not cause any meaningful difference on their self-confidence, and that not only the athletes who won the medals but also the athletes who participated in the trainings, competitions, events and competitions in individual and team sports increased their respect and confidence.

According to the results of the analysis, there is no significant difference between the internal self-confidence and external self-confidence scores of the secondary school students participating in the study according to the sport age variable. Hofstetter, Hovell and Sallis (1990) support the results of our study in their study on individuals who started sports at an early age.

\subsection{Evaluation of Measures between Motivation and Gender, High School Type, Sport Age, Sport Branch and Sport Category Variables}

According to the results of the analysis, there was no statistically significant difference between non-motivation from sub-dimensions of motivation scale, intrinsic motivation, external motivation sub-dimensions of the secondary school students participating in the study and gender variable. In his study, Aktaş (2016) concluded that there is no effect of gender on the external motivation level of the students. In contrast to the present study, Martinovic et al. (2011) investigated the effects of gender difference on sports participation and motivation in 706 primary school students aged between 11 and 14 years, and statistically significant differences were found between girls and boys.

According to the results of the analysis, the difference between the sub-dimensions of the motivation subscale of the secondary school students participating in the research and the values of impulse, intrinsic motivation, external motivation sub-dimensions and gender variable were not statistically significant. According to this; regardless of gender discrimination, it can be said that both male and female athletes are motivated at a similar level in terms of motivation levels. Moreover, it can be considered that there is no difference between motivation levels, since male and female athletes may exhibit poor performance due to fear of taking risks, self-confidence, self-fulfillment sensation, or fear of failure.

According to the results of the analysis, it was found that there was a significant difference between the non-motivation, intrinsic motivation and extrinsic motivation scores of the secondary school students' motivation scale sub-dimension according to the high school type variable. Accordingly, in the internal and external motivation dimension, the mean score of the students studying at the school was higher than the average scores of the students studying at other schools. In the non-motivation dimension, the mean scores of the students studying in school VII were higher than the average scores of the students studying in other schools.

It can be said that the number of facilities, teachers, trainers and athletes is higher in School I than in other high schools. The fact that high schools that are successful in sports competitions have more medals may cause students to be motivated. It can be said that athletic student profiles of School I are more different, their education structures are stronger, their understanding of service and strategies related to sports training are more prominent and they show a more serious approach to athlete training studies. In addition, it can be said that the support of their parents for participation in sports competitions and the extrinsic motivations of the students in the classroom and friendship 
environments create differences depending on high school type. Aktaş (2016) examines the sources of motivation of high school students and the sources of extrinsic motivation of high school students vary according to the type of school. While the extrinsic motivation levels of the students with science type were the highest, it was found that the extrinsic motivation levels of the students of the School IV were the lowest.

Aksu (2016) find referees with 7 years seniority have higher level self-confidence when compared to referees with 1-3 years seniority.

According to the results of the analysis, no significant relationship was found between the sub-dimensions of motivation according to the gender, sports branch, sports age and sport category of the secondary school students participating in the research.

According to the results of the analysis, there is no significant difference between the internal motivation and external motivation and non-motivation sub-dimension scores of the secondary school students participating in the study. The reason why there is no difference between the age variable and motivation can be said that there is not much difference and expectations between the earnings-based sports and sports done without any financial gain. The findings of the study by Hossein Alipour (2015) are in parallel with these results. According to the results of the analysis, it was found that there was no significant difference between the motivation sub-dimension scores of the secondary school students participating in the study according to the sport age variable. Research findings by Hossein Alipour (2015) are in parallel with these results.

According to the results of the analysis, it was found that there was no significant difference between the motivation sub-dimension scores of the secondary school students participating in the study according to the sports category variable. In his study, depended on the evaluation, Hosseinalıpour (2015) did not find any statistically significant difference between the motivation scores of the athletes who performed football, volleyball, basketball, taekwondo and athletics sports in terms of doing amateur or professional sports variable.

\section{Results and Suggestions}

1. It was concluded that there was a significant difference between the gender variable of the high school students participating in the school sports competitions and the sub-dimension of the intrinsic self-confidence.

2. It was found that high school students participating in school sports competitions had significantly different intrinsic self-confidence scores and extrinsic self-confidence scores, which are sub-dimension of self-confidence according to high school type variable.

3. It was found that there was a significant difference between the self-confidence sub-dimension of the high school students who participated in the school sports competitions and the intrinsic self-confidence scores and the extrinsic self-confidence scores.

4. A significant difference was found between intrinsic and extrinsic motivation scores of high school students who participated in school sports competitions according to the high school type variable.

5. A very high positive correlation was found between intrinsic motivation and extrinsic motivation.

In conclusion, it is seen that motivation and self-confidence factors have an important place in high school students who participate in sports competitions. Therefore, this is a variable that influences the success and performance, motivation and self-confidence of the student during the competition, and it should be carefully considered by coaches, families and teachers. It can be said that identifying achievable targets, creating comfortable and safe competitions, providing students with opportunities and encouraging them to participate in more sports competitions reduce anxiety and increase student motivation and self-confidence.

Therefore, determining the roles and skills of sports branches and shaping the planning processes in accordance with the results of the competition positively influences the students' success and affects their motivation and self-confidence significantly.

\section{REFERENCES}

[1] Abakay, U. (2010). Futbolcu antrenör iletişiminin farkl statülerdeki futbolcuların başarı motivasyonuyla ilişkisi. Yayınlanmamış doktora tezi, Gazi Üniversitesi, Ankara.

[2] Akın, A. (2007). Öz-güven ölçeğinin geliştirilmesi ve psikometrik özellikleri. Abant İzzet Baysal Üniversitesi Eğitim Fakültesi Dergisi, 7(2), 167-176.

[3] Aksu, A. (2016) Farklı klasmanlardaki futbol hakemlerinin karar verme stilleri ve özgüven düzeylerinin incelenmesi Yayınlanmamış yüksek lisans tezi, Fırat Üniversitesi, Elazığ.

[4] Aktaş, N. (2016). Lise öğrencilerinin motivasyon kaynakları ve karar verme stratejileri. Yayınlanmamış yüksek lisans tezi, Adnan Menderes Üniversitesi, Aydın.

[5] Aktaş, Z., Çobanoğlu, G., Yazıcılar, İ. ve Er, N. (2006). Profesyonel basketbolcularda spora özgü başarı motivasyon düzeyinin cinsiyetler açısından karșılaştırılması. Spormetre Beden Eğitimi ve Spor Bilimleri Dergisi, 4(2), 55-59.

[6] Aracı, H. (2006). Okullarda beden eğitimi. Ankara: Nobel Yayın Dağıtım. 
[7] Arslan, A. Doğanay, H. Kırık, A. M. ve Çetinkaya, A. (2015). Lise öğrencilerinde spor yapma ve özgüven ilişkisi. Spor Sağlık ve Tıp Bilimleri Dergisi, 17(1), 21-30.

[8] Bilgin, O. (2011). Ergenlerde özgüven düzeyinin bazı değişkenler açısından incelenmesi. Yayınlanmamış yüksek lisans tezi, Sakarya Üniversitesi, Sakarya.

[9] Ekinci, H. (2013). Müzik öğretmeni adaylarının solo sahne performansına ilişkin özgüven algılarının bazı değişkenler bakımından incelenmesi. Mehmet Akif Ersoy Üniversitesi Eğitim Bilimleri Enstitüsü Dergisi, 2(2), 52-64.

[10] Ekiz, D. (2013). Bilimsel araştırma yöntemleri. Ankara: Anı Yayıncilı.

[11] Erciş, S. (2012). Türkiye'deki devlet ve vakıf üniversitelerinin spor müsabakalarındaki verimliliklerinin veri zarflama analizi (vza) ile göreceli olarak değerlendirilmesi ve karşılaştırılması. Yayınlanmamış doktora tezi, Atatürk Üniversitesi, Erzurum.

[12] Hofstetter, C. R., Hovell, M. F. and Sallis, J. F. (1990). Social learning correlates of exercise self-efficacy: Early experiences with physical activity. Social Science and Medicine, 31(10), 1169-1176.

[13] Hosseinalipour, F. (2015). Üniversiteli öğrencilerin sporda motivasyon düzeyleri ve stresle başa çıkma yöntemlerinin incelenmesi. Yayınlanmamış yüksek lisans tezi, Gazi Üniversitesi, Ankara.

[14] Kılınç, M., Ulucan, H., Kaya, K. ve Türkçapar, Ü. (2012). Takım sporu yapanların motivasyon düzeylerinin farklı değişkenlere göre incelenmesi. Abant İzzet Baysal Üniversitesi Eğitim Fakültesi Dergisi, 11(2), 133-144.

[15] Martinović, D., Ilić, J. and Višnjić, D. (2011). Gender differences in sports involvement and motivation for engagement in physical education in primary school. Problems of Education in the 21st Century, 31, 94-100.

[16] Öncü, H. (2003). Motivasyon (güdülenme). L. Küçükahmet (Ed.), Sınıf yönetimi içinde (s. 83-84). Ankara: Nobel Yayınları.

[17] Özkara, A. B. (2018) Physical education in EU schools and Turkey: A comparative study. Comparative Professional Pedagogy 8(2), 101-106.

[18] Özkara, A. B., Kalkavan, A., Alemdag, S., \& Alemdag, C. (2016). The role of physical activity in psychological resilience. Sport and Health, 24-29.

[19] Özkara, A. B., Kalkavan, A., Alemdağ, S., Alemdağ, C., \& Çavdar, S. (2017). The role of physical activity in pre-service teachers' subjective vitality. Physical education of students, (3), 134-139.

[20] Pelletier, L. G., Tuson, K. M., Fortier, M. S., Vallerand, R. J., Briere, N. M. and Blais, M. R. (1995). Toward a new measure of intrinsic motivation, extrinsic motivation, and amotivation in sports: The Sport Motivation Scale (SMS). Journal of Sport and Exercise Psychology, 17(1), 35-53.

[21] Şirin, E. F., Çağlayan, H. S., Çetin, M. Ç. ve Alpaslan, İ. N. C. E. (2008). Spor yapan lise öğrencilerinin spora katılım motivasyonlarına etki eden faktörlerin belirlenmesi. Beden Egitimi ve Spor Bilimleri Dergisi, 2(2), 98-110.

[22] Yetim, A. A. (2015). Sosyoloji ve spor. Ankara: Berikan
Yayınevi.

[23] Yetim, A. ve Cengiz, R. (2010). İletişim ve spor. Ankara: Berikan Yayınevi.

${ }^{\mathrm{i}}$ This study is based on the Ph.D. thesis of the first author 